\title{
The Ties that Bind: Ethnicity, Pro-Government Militia and the Dynamics of Violence in Civil War
}

Luke Abbs (Essex University)

Govinda Clayton (ETH Zurich)

Andrew Thomson (Queens University Belfast)

\begin{abstract}
:
Existing research reveals many of the ways pro-government militia (PGM) shape civil violence, but overlooks how the ethno-political ties between the state and a PGM might influence these effects. We argue that co-ethnic militia (i.e. groups composed of the ruling elite's ethnic kin) are relatively loyal irregular forces that multiply state military capacity. The greater loyalty of co-ethnic groups also mitigates principal-agent problems but further polarises ethnic communities, and as a result, co-ethnic PGMs are likely to be associated with longer and more intense civil conflict. We test this argument on a global sample of cases from 1989-2007, using new data capturing the ethnic ties of all pro-government militia. The results support our claims that co-ethnic militia are associated with more intense and longer civil conflict.
\end{abstract}

Key Words: Ethnicity, Pro-Government Militia, Counter-Insurgency, Civil War, Conflict Intensity, Conflict Duration

Words $-10,841$ 
How do pro-government militia (PGM) influence the dynamics of violence during civil conflict? We develop existing theoretical accounts of how and why PGMs shape violent conflict by incorporating co-ethnic PGM — an armed force that is clearly pro-government, not identified as a part of the regular security force, and recruited specifically from the ruling elite's ethnic kin to undertake tasks in support of their ethnic group (or a coalition of groups). PGMs have recently been shown to influence a range of conflict conditions, including: regime survival; coups d'etat; human rights violations; one-sided violence; civil-war intensity; and insurgent fragmentation (e.g., Carey, Colaresi and Mitchell, 2016; Jentzsch, Kalyvas and Schubiger, 2015; Carey, Colaresi and Mitchell, 2015; Roessler, 2011; Pilster and Böhmelt, 2011). Yet to date, research overlooks how the ethno-centric recruitment of many PGMs might influence their effect.

We argue that the strength of ties between the state and PGMs shape their influence on civil violence. Civilians are more likely to join a militia and engage in violence when they are strongly bound to the state and have a common interest in the military outcome. Moreover, according to a principal-agent logic, PGMs (i.e. agents) that operate outside of the state's (i.e. principal's) control are often likely to engage in actions to improve their position. This is particularly the case when the PGM operates in a high-risk context in which compliance with the state's orders carries significant dangers for the agent. Whilst previous research often highlights the principal-agent problem facing states that use a PGM, far less work has discussed the strategies states use to mitigate this problem, particularly within the context of ethnic politics, and the implications that this might have on civil violence. We argue that co-ethnic recruitment is one method often used by the state to strengthen ties to the PGM, and reduce commitment concerns resulting from the principal-agent problem.

Broadly speaking, ethnically motivated recruitment can lead to two forms of ethnic militia: co-ethnic PGM and defector PGMs. Co-ethnic PGM are those composed of the ruling 
elite's ethnic kin (e.g. Hutu Interhamwe in Rwanda and the Shiite militias in Iraq). Defector PGMs also fight on behalf of the state, but are composed from the anti-government population, often ethnic groups that are excluded from power (e.g. Kurdish Village Guard in Turkey, or Home Guard in Kenya), and/or former members of an ethnic insurgent group (e.g. former Tamil rebel groups that joined forces with the Sinhalese dominated Sri Lankan government).

Co-ethnic PGMs have strong ties to the ruling elite, and offer a recruitment advantage during armed conflict that makes them highly effective force multipliers. We therefore expect co-ethnic PGMs to be associated with greater levels of violence during civil conflict. Despite the challenges associated with high intensity violence, the loyalty of co-ethnic PGMs means that they suffer less from principal-agent problems. Yet the ethnicized environment they create and their willingness to continue fighting increases polarisation between communities. We expect the observable implication to be that co-ethnic PGM are more likely to be associated with intense and longer periods of civil conflict, which is not necessarily the case for other less connected and loyal forms of PGM. We test these arguments on a global sample of cases from 1981-2007, using new data capturing the ethnic ties of PGMs. The results support our claims.

\section{Pro-Government Militias}

PGMs are organized armed groups aligned with the incumbent government, but not part of the “official” state armed forces (Carey, Mitchell, and Lowe, 2013: 250). PGMs include a heterogeneous collection of non-state actors that differ in their recruitment base, composition, activities, and targets. For example, death squads, warlords, and civilian defence forces differ in terms of their link with the state (e.g. semi-official or informal), theatre of operations (e.g. local or national), and whether they operate within or outside of armed conflict (see, Carey and Mitchell, 2017; Böhmelt and Clayton 2017). 
Previous research demonstrates that PGMs are likely to emerge in weak states facing acute security threats, including, but not limited to, insurgency and civil war (Böhmelt and Clayton 2017; Carey and Mitchell, 2017; Jentzsch, Kalyvas and Schubiger, 2015). Under such conditions, PGMs can emerge from civil society as local security providers in response to insurgent violence (Barter 2013; Aliyev 2016). Governments also often mobilize or co-opt PGMs as force multipliers in pursuit of short-term advantages; they are cost-effective in comparison to conventional forces and are more quickly recruited (Staniland 2012; Jentzsch et al, 2015; Carey, Colaresi and Mitchell, 2016). Some types of PGMs also enable the government to evade accountability for human rights abuses (Kirschke, 2000; Carey, Colaresi and Mitchell, 2015; Stanton, 2015). Other forms of PGMs, such as civilian defence forces, can provide local knowledge that enables the government to better identify insurgents (Clayton and Thomson 2016; Kalyvas, 2006; Lyall, 2010; Staniland, 2012). This is particularly effective when the state incorporates former members of the insurgency into a militia (Kalyvas, 2006; Staniland, 2012). Finally, parallel-military PGMs can counterbalance conventional forces and mitigate internal threats, such as coups (Pilster and Böhmelt, 2011; Carey, Colaresi and Mitchell, 2016).

However, recent research has shown that these short-term advantages can have negative consequences, arguing that the presence of PGMs can (generally) exacerbate and prolong conflict, either because states are unable to control militias or they are unwilling to do so. Using a principal-agent framework some have argued that the nature and strength of the state-PGM relationship helps to determine levels of violence against civilians, showing that the presence of informal PGMs, those with only informal links to the state, compared to those with a semiofficial status, can increase human rights violations (Mitchell, Carey and Butler 2014; also see Stanton 2015; Kirschke 2000). Once a state has conceded their monopoly over the legitimate use of force to PGMs, the state can subsequently struggle to control PGM violence. According to a slightly different logic, since states often use PGMs to plausibly deny responsibility and 
evade accountability for violent actions taken on their behalf, the use of PGMs with informal links to the state (i.e. weaker connections) signals a higher tendency towards intense violence and civilian victimization (Carey, Colaresi and Mitchell 2015; Koren 2017). Others see the presence of multiple armed organizations (state institutions as well as paramilitary forces and PGMs) as associated with more intense violent conflict (Böhmelt and Clayton 2017; Raleigh 2016).

In addition to more violent conflict, the evidence also suggests that the use of PGMs can increase the duration of a dispute (Aliyev 2017, 2018; Carey, Mitchell and Scharpf, 2018). For example, Aliyev (2017) finds that conflicts in which PGMs are present tend to last around 3 times as long as conflicts in which PGMs are not present. Aliyev (2018) also finds that PGMs can prolong civil conflicts by making a negotiated settlement less likely and reducing the possibility of one side winning, re-producing low-intensity conflict. It is not yet clear if this extends to other forms of civil violence, or if the relationship is dependent on the type of militia force (beyond the link to the government).

PGM interactions with rebels may also prolong violent conflict. PGMs are usually antiinsurgent in nature and often target rebels during state-rebel peace talks, increasing the chances of spoiler activity (Steinert, Steinert, and Carey 2018; Aliyev 2018). Peace can also threaten the existence of PGMs by undermining their relationship with state benefactors and endangering their access to sources of income. Ending a conflict, whether through victory, defeat, or negotiation, poses an existential threat to PGMs, therefore increasing the likelihood that these actors will be opposed to ending the conflict.

Whilst in some cases the conflict-enhancing effect of militias might be desirable for the incumbent in the short-term, losing control of a PGM is unlikely to be favoured by the state. For once the genie is out the bottle there is no guarantee that a PGM will remain loyal and 
produce the desired outcome. As such, existing literature pitches the use of militias as a dilemma in which states must often choose between maintaining a force monopoly that can be crucial for stability, economic development and the establishment of the rule of law, and a reduction in control over violent actors in return for the benefits associated with PGMs (Böhmelt and Clayton 2017; Carey and Mitchell 2016; Mitchell, Carey and Butler 2014). We extend previous work in arguing that states often attempt to mitigate this principal-agent problem by recruiting militia with stronger ethnic ties to the state and that are expected to remain loyal. We focus on ethnicity in state-PGM ties before explaining incumbent incentives to use co-ethnic PGMs and the consequences this has for civil war dynamics.

\section{Ethnic Pro-Government Militias}

The salience of ethnicity is a prominent explanation for variation in the nature of civil violence. Conflicts fought over ethnic motivations are often both more deadly and last longer than ideological or opportunistic disputes. Yet the mechanisms through which ethnicity influences conflict remain contested (Lyall 2010; Kalyvas 2008; Seymour 2014; Warren and Troy, 2015). Most accounts associate intractable ethnic violence with the greater capacity of ethnic groups to overcome problems of collective action, and the greater intensity in which ethnic violence can polarize communities. Ethnic-based grievances often hold greater salience and offer a mobilization advantage for rebels recruiting from ethnic groups that are excluded from political power (Weinstein, 2007; Wucherpfennig, et al, 2012; Cederman, Gleditsch and Buhaug, 2013). The ascriptive nature of ethnicity also means that disputes can quickly escalate, further undermining a bargaining process (Eck 2009; Kaufmann 1996).

However, existing accounts tend to define ethnic conflict monadically (i.e. conflict as a whole) or dyadically (i.e. relationship between the state and a rebel organisation). The former 
approach offers a useful indication as to how conflicts with an ethnic dimension differ from those without, yet are poorly suited to distinguish between the different mechanisms that might produce this effect. Dyadic approaches offer greater potential to uncover support for a specific relationship, yet to date, the focus has been solely on the ethnic characteristics of the government (e.g. Cederman, Gleditsch and Buhaug, 2013) or rebel forces (e.g. Wucherpfennig et al 2012), overlooking the influence of irregular state forces.

As we are interested in explaining how the ethno-centric connections between the state and a PGM condition the latter's influence on civil conflict dynamics, our focus is limited to PGMs, as distinct from other forms of militia, ethnic or otherwise, that are not pro-government. We do not discount the possible importance of other armed organisations, often referred to as “militias”, that may be ethnically mobilised, pro-rebel/anti-state or have no affiliations to armed actors at all (e.g. Raleigh 2016; Alden, Thakur and Arnold 2011). Yet given the scope of this paper, we limit our discussion to PGMs.

Ethnicity can be associated with PGMs in a number of ways (see Magid and Schon 2018; Aliyev and Souleimanov 2018). We consider a militia group to be an ethnic progovernment militia (EPGM) when a militia is clearly pro-government, not identified as a part of the regular security force, and are recruited specifically along ethnic lines, in order to uphold ethnic goals. EPGMs can be composed of individuals from a single ethnic group, or occasionally, a coalition of ethnic groups. Shared ethnic identity (whether real or imagined) forms the basis for militia recruitment, and thus inclusion or exclusion within the PGM. This is a common recruitment practice, for example the Uzbek Junbesh-e-Milli in Afghanistan, which recruit exclusively from the Uzbek community. PGM might also include non-native groups recruited from transnational ethnic kin. For example, the Army for the Liberation of Rwanda operates in the DRC alongside their Congolese Hutu kin. In addition, EPGMs are 
formed (or co-opted) to uphold ethnic goals, such as the maintenance of a favourable political or economic distribution, or the protection of a specific part of the civilian population.

Rather than seeing ethnic linkages as purely demographic, we place ethnic goals and civil war within the context of ethno-exclusive politics and contestation between ethnic groups that are included and excluded from political power (Wucherpfennig et al, 2012; Cederman, Gleditsch, and Buhaug, 2013). The government is not only active in the conflict but can also be ethnically biased. Ethnic incumbents often openly deploy ethno-exclusive policies as a strategy to consolidate the power and security of their own ethnic group and distribute state resources (i.e. patronage) to co-ethnics in exchange for political support (Posner, 2005; Roessler, 2011; Wimmer, 2013). ${ }^{1}$

Incumbent incentives to co-opt or recruit EPGMs differ depending on whether they recruit from their own ethnic constituency (co-ethnics) or recruit from groups that are formed from the anti-government population (defectors). In turn, these types of EPGMs have different incentives to fight on behalf of the government. These differences are likely to influence the strength of the state-EPGM relationship, shaping EPGM loyalty to the state and commitment as a fighting force. Based on these varying ethnic ties we distinguish "co-ethnic PGMs" and “defector PGMs”. We believe this relational perspective posits that the strength and reliability of state-PGM relationship is important in determining conflict outcomes.

Existing literature has largely focused on defector PGMs. Defector PGMs are composed of local recruits drawn from the predominantly anti-government population, and thus whose use of violence in support of the state is explicitly opposed to the national aspirations of the ethnic group that they identify with (Magid and Schon 2018; Kalyvas 2008). Defector groups are normally composed of groups that are excluded from power, and also often include former members of an ethnic insurgency. 
Counterinsurgency research points to a set of tactical advantages associated with defector PGMs, including disrupting rebel access to supporting communities and offering local knowledge on insurgents, which improve the selectivity of state targeting through overcoming the "identification problem” (Kalyvas 2008; Lyall 2010;). These advantages are particularly acute where defector PGMs are recruited from side-switching or former rebel members (Clayton and Thomson 2016; Staniland 2012). Defector PGMs also help to "legitimize" the actions of the regime by challenging insurgent claims to be the sole representative of the excluded ethnic group, undermining intra-ethnic cohesion (Lyall, 2010). In turn, recruits have incentives to join a defector PGM in order to gain token patronage from the state or seek state support in order to achieve predominance within their own consistency and gain security from rival factions.

Yet incumbents can be less confident that the private incentives of a defector PGM are similar to their own, not least because they are formed from politically excluded, antigovernment populations which are prone to side-switching (Seymour, 2014). Despite the short-term advantages of defector PGMs, their weak links to the state mean they are unlikely to be of sufficient size or loyalty to be considered a viable long-term strategy. Moreover, the lack of ties between the state and ethnic defector PGMs' communities and loyalties to their ethnic group are likely to hinder widespread recruitment into defector PGMs. For example, the Kurdish Village Guards in Turkey were branded as "traitors" for their opposition to the PKK and were marginalized within Kurdish communities, helping to prevent mass conscription (Gurcan, 2015). Defectors also have a proven history of desertion if confronted with significant threats during intense periods of violence (Souleimanov, Aliyev, and Ratelle 2018).

On the other hand, states have different incentives to mobilize or co-opt co-ethnic groups. Incumbents often try to preserve their ethnic groups' privileged position and ensure their regime's survival in ethno-political exclusionary contexts by limiting military 
recruitment, advancement and patronage to their ethnic kin, and thereby maintain control over military institutions (e.g. Harkness, 2016). Recruiting from ethnic kin is more likely to provide a convenient way of organizing armed recruitment, as it is often more salient and 'sticky' than other recruitment categories (e.g. ideology) (Eck, 2009; Cederman, Gleditsch and Buhaug, 2013; Jentzsch, 2014). Due to its salience, recruitment along ethnic lines lowers coordination costs and makes potential loyalists and recruits more easily identifiable (Eck, 2009).

Some incumbents have attempted to build co-ethnic armies and promote co-ethnics to key military positions. Yet this process of 'ethnic stacking' is relatively rare because it is difficult to implement and is often not a viable option during armed conflict. Attempts to build ethnic armies, or reform those created by their predecessors, often motivates coups and violent resistance from military officers of out-groups as well as counter-coups (Harkness, 2016). In the Central African Republic (CAR), President Patassé's attempts to promote Northern military personnel led to three ethnic mutinies by Southern factions of the army. In most cases, incumbents inherit multi-ethnic armies, and thereby cannot ensure the loyalty of certain factions within the security forces. For instance, various Tutsi army commanders in the Forces of the Democratic Republic of the Congo have defected during armed rebellions.

Moreover, a state’s capacity to engage in violence also depends upon the strength and depth of the armed forces. Civil conflict more commonly occurs in weak states that lack presence in peripheral hard-to-reach areas and have limited conventional military capacity to repel insurgent threats. To influence the military dispute, weak states often require quick force multipliers and rely on large numbers of civilians who are willing to take up arms for their cause (Böhmelt and Clayton, 2017), and within the context of ethnic politics, hold sufficient loyalty that they remain committed throughout intense periods of violence. 
A common strategy is to mobilize or co-opt irregular PGM forces that share a similar ethnicity to the incumbent government. Incumbents delegate violence to co-ethnic PGMs in order to circumnavigate the principal-agent problem (Kirschke, 2000; McLaughlin, 2010) and augment military capacity while evading responsibility for violence (Raleigh and Kishi 2018). Ruling elites can be more confident that militia groups share similar incentives when they are comprised of in-group members. Co-ethnic PGMs, in turn, are motivated to protect a statusquo that is advantageous to their group, including a favourable share and distribution of economic and state resources.

Additionally other private incentives are also more likely to be compatible with the incumbents'. For example, whilst co-ethnic PGMs might have incentives to engage in deviant behaviour that undermines state control; looting, sexual violence and personally motivated attacks, these actions are more likely to be targeted at opposing ethnic groups, rather than the constituencies upon which incumbents depend. Incumbents therefore have incentives to use co-ethnic PGMs as 'protection forces' to maintain ethno-political power, pitting them as counterinsurgents against insurgent forces from other ethnic groupings (Schneckener, 2006:26). For example, various administrations in the Philippines have relied upon coChristian PGMs to target Muslim separatists in Mindanao, and similarly with the Anti-Terrorist Unit in Liberia where Charles Taylor specifically recruited from Gio and Mano to supress excluded ethnic opposition forces. Building on this overview of defector PGMs and co-ethnic PGMs, we argue below that co-ethnic PGMs are likely to have clear and observable consequences on violence during civil war.

\section{Co-ethnic Pro-Government Militia and the Dynamics of Civil War}

Co-ethnic PGMs and Conflict Intensity 
We expect that co-ethnic PGM-government ties will be associated with high-intensity conflicts. Firstly, co-ethnic PGMs are expected to be associated with greater civil violence on account of the recruitment advantage that they offer. As discussed above, the stronger ties between the state and a co-ethnic militia provides the basis for quick mobilization of a committed and loyal fighting force, which can facilitate increased levels of civil violence (e.g. Eck 2009). Due to their salience, common ethnic ties form a clear obligation for members to protect their group's collective common interests (Wucherpfennig, et al, 2012). Co-ethnic PGM recruits share in the spoils of ethno-political power, rendering such groups more likely to remain loyal and fight on to uphold the favourable co-ethnic regime (Kirschke, 2000; McLaughlin, 2010). In this way, co-ethnic groups serve as loyal force multipliers, bolstering state military capabilities and allowing the state to more quickly and violently respond to challengers. For example, the creation of co-ethnic militias was pivotal to sustaining Bashar al-Assad's regime in Syria. Assad was able to escalate the dispute to resist growing rebel threats in the early phases of the conflict largely due loyal Alawite force of 60,000 men, quickly recruited under the banner of the National Defense Force (Carter Center, 2013). This loose collection of co-ethnic militia prevented rebel advances by intensifying the violence at the local level, challenging rebel control neighborhood by neighborhood across the state.

Second, the strength of the state relationship with co-ethnic PGMs can also influence the intensity of civil violence by in effect accentuating the information problem. Co-ethnic militia (by definition) do not share common ethnic ties with insurgent groups or the communities from which they hail. Without intimate knowledge of their "enemies" and the communities in which they reside, co-ethnic PGMs are therefore more likely to employ indiscriminate forms of violence against perceived enemy groups, rather than selectively target insurgents (Aliyev and Souleimanov 2018; Kalyvas 2006). For violently targeting civilians groups in which insurgents reside, and those of similar ethnic makeup to the insurgents, is often 
believed to weaken challengers, and is more likely when actors are mobilised on the basis of ethnic identity (Fjelde and Hultman 2014).

Thirdly, since co-ethnic militias are created or co-opted to preserve exclusionary ethnopolitical hierarchies, they can often escalate and exacerbate ethnic divisions increasing the intensity of violence between groups (Eck, 2009; Roessler, 2016). For members of co-ethnic PGMs, on account of their recruitment and composition, are prone to extreme ethnic views, and thus view ethno-political dominance as legitimate and justified. This is likely to lead to greater violence between groups. An earlier study offered some preliminary evidence to this effect, showing that co-ethnic militia in African conflicts that are committed to defending a particular ethnically defined political party, regime, or elite, tend to perpetrate higher levels of human rights violations than other types of ethnic PGMs (such as defectors) (Magid and Schon 2018). On some occasions this violence might be the intention of the ruling regime, who use militia forces to avoid responsibility for violence used on their behalf (e.g. Raleigh and Kishi 2018; Carey, Colaresi and Mitchell, 2015). In other cases, it might be the by-product of using PGMs that are less accountable and less disciplined than the official armed forces. Thus despite the increased loyalty of co-ethnic PGMs to the state, such unofficial forces are likely to continue to pose significant risks to civilians. This is particularly the case for members of ethnic out-groups.

For example, during both Sudanese civil wars, the government enabled the mobilization of Arab-Muslim militias by appealing to a common identity to tackle insurgents composed predominantly of African ethnic groupings (Johnson, 2003: 44-49, 83; Idris, 2005: 53-56; Martin, 2002: 120). The Sudanese Armed Forces were composed of conscripts from a variety of ethnic groups and tribal affiliations, meaning they were often reluctant to commit violence against their perceived ethnic kin (Idris, 2005: 88; Martin, 2002: 117). In comparison, co-ethnic PGMs were often more loyal to the state and willing to exercise violence in a way that both 
augmented state capacity and limited state accountability for actions taken on its behalf. The ability of the state to quickly mobilize a significant militia force composed of co-ethnic groups was an advantage that intensified the violent dispute and exacerbated inter-ethnic tensions between the Arab-Muslim and African populations (Idris, 2005). Similarly, in response to mounting opposition in Darfur, the government of Sudan was able to rely on a swift and significant military offensive using the Janjaweed that escalated the conflict across the region, in particular through the use of widespread indiscriminate violence and the exacerbation of ethnic tensions. In both cases, the recruitment of co-ethnic militias were pivotal in escalating violence. From this discussion we derive our first hypothesis:

Hypothesis 1: Conflict months in which co-ethnic PGM are present are likely to be associated with more conflict fatalities than conflict months in which co-ethnic PGMS are absent.

\section{Co-ethnic PGMs and Conflict Duration}

Government ties with co-ethnic PGMs are also likely to influence the duration of a dispute. Firstly, as we discussed above, the recruitment advantage associated with co-ethnic PGM creates larger and more loyal forces. This increases the resilience of a regime, in particular its ability to sustain long periods of fighting. Irregular forces are prone to defection and side-switching during civil conflict, and according to a principal-agent logic, PGMs (i.e. agents) that operate outside of the state's (i.e. principal's) control are often likely to renege on their commitment if not sufficiently monitored or enforced. This is less of a problem for coethnic actors, as they share in the benefits of ethno-political power, and are more likely to remain loyal throughout an armed struggle (Kirschke, 2000; McLaughlin, 2010). The existent system of patronage and government's promises of future benefits further cement this loyalty 
(Eck, 2009). Conversely, if defeated, co-ethnic groups (and their kin) are at serious risk of deadly reprisals further increasing their loyalty and commitment (Eck, 2009; Kirschner, 2010).

Yet despite the recruitment and subsequent loyalty gains associated with co-ethnic PGMs, these advantages are often insufficient to comprehensively win a conflict. In comparison to state forces, they tend to be poorly trained, equipped and lacking in specialisation (Böhmelt and Clayton 2017). Thus the additional numbers tend only to offer a defensive advantage, reducing the likelihood of defeat and the need to make significant concessions. For example, in Angola the Civil Defence Organisation, comprised from the governing Mbundu group, helped provide state protection by creating an additional protective zone around the capital, rather than actively engaging the insurgent force. As such, whilst coethnics can often help to sustain a dispute, they rarely hold the capacity to comprehensively defeat an opponent.

Co-ethnic PGM are also likely to influence the duration of conflict by further exacerbating inter-ethnic divisions. The use of ethno-exclusive forces associates violence and ethnicity, increasing "politicization of identity-based cleavages” (Alden, Thukur and Arnold 2011: 37-39; Montalvo and Reynal-Querol, 2010). This prevents effective bargaining prior to violence (Roessler, 2011), and hinders peacemaking during war (Denny and Walter, 2014). While this might help the state to recruit from its own population, as the process that exacerbates interethnic competition also produces intra-group cohesion (Kaufmann, 1996), it simultaneously enhances the rebel's ability to recruit and gain support among their ethnically excluded constituency (Denny and Walter, 2014). This reduces the likelihood of peaceful resolution and the prospect of a conflict petering out. For example, in Indonesia heavy-handed tactics, including the use of Javanese militias, helped to boost support for Acehnese separatists. In Sudan the mobilization of PGMs along exclusionary ethnic lines intensified the shared ethnic identity and “Arabness” among recruits but polarized their “African” neighbours (Idris, 2005), 
which enhanced the ability of insurgent factions to mobilize among excluded ethnic groups. Over time, this has entrenched ethnic divisions between the north and the south that helped to sustain recruitment for violence.

Similarly, by recruiting along ethnically exclusionary lines, co-ethnic PGMs are more prone to extreme ethnic views, and thus become spoilers in any process that might challenge their domination (Cederman, Gleditsch and Buhaug, 2013). More generally, co-ethnic PGMs are therefore likely to resist policies that jeopardize their prominent position (Staniland, 2012). In this context, the loyalty of a co-ethnic PGM pivots from the ethno-political regime to the broader group they claim to represent (Carey and Mitchell, 2017). For example, in Ukraine, EPGMs have constantly undermined the government, which they now accuse of betraying the Ukrainian people in seeking negotiations with the rebels (Aliyev, 2016). Taken together the above discussion leads to a second observable implication.

Hypothesis 2:- Civil conflicts in which co-ethnic PGM are present are associated with longer civil conflict duration than civil conflicts in which co-ethnic PGM are absent.

\section{Research Design}

Measuring Ethnic PGMs

Co-ethnic PGMs are the key independent variable in our analysis. We first operationalize EPGMs using the Pro-Government Militia (PGM) dataset (Carey, Mitchell, and Lowe, 2013). The PGM dataset includes 331 PGMs active between 1981 and 2007, and offers the original news sources used to code each militia group. We use this online database, and where necessary evidence from other sources to apply our coding criteria for EPGMs. In total, we coded 186 of the 331 militias as EPGMs. ${ }^{2}$ We coded EPGM that meet both of the following criteria: 
1. Recruitment: PGM membership is restricted to a specific politically relevant ethnic group (or groups). ${ }^{3}$ There needs to be clear evidence of an ethnic criterion associated with group membership. ${ }^{4}$ For example, the Uzbek Junbesh-e-Milli in Afghanistan. Recruitment is not limited to one ethnic group, as sometimes EPGMs are composed of different ethnic constituencies. ${ }^{5}$

2. Role: activities support a particular ethnic group (or a coalition of groups). To ensure that ethnic mobilization is not a strategy of convenience, we also require evidence that the group seeks to support or threaten a particular group based on ethnicity. This excludes mercenary groups operating for economic motivations, such as Chadian groups operating in CAR.

Having coded each EPGM, we then link these militias to their respective ethno-political power status using the Ethnic Power Relations dataset (EPR) (Wimmer, Cederman and Min, 2009). Our approach develops the method previously used to capture the ethnic characteristics of insurgents (e.g. Wucherpfennig et al. 2012). We first identify the politically relevant ethnic group(s) that the EPGM represents, then match this to the EPR data to determine if that group(s) linked to that militia are included or excluded from political power. ${ }^{6}$ EPGMs recruited from a ruling group (or coalition) are coded as co-ethnic PGM. For example, the Special Security Service in Liberia was set up by Charles Taylor to uphold government power, and recruited specifically from his Gio and Mano support base. ${ }^{7}$ To code defector groups, i.e. those composed of ethnically defined anti-government populations, we record which militia were composed of individuals from the same ethnicity as the rebels. Finally, we code the rare EPGMs that do not share the same ethnicity as the government or insurgents (non-coethnic PGMs). We lag our independent variables to ensure causal ordering, otherwise we risk 
including PGMs that are active after a conflict has intensified in a given month on the righthand side. We rerun all analyses using non-lagged variables in the appendix.

We adjust our coding to changes in ethno-political power. This is illustrated by the Uzbek Junbesh-e-Milli which are only classified as co-ethnic between 1993 and 1996, as this is the only period Uzbek representatives had posts in the executive. Of the 186 EPGMs, we classify 135 as co-ethnic PGMs and 54 as defector PGMs. As figure 1 shows, co-ethnic PGMs are a global phenomenon, but are more common where ethnicity is salient.

Figure 1: Global Distribution of Co-ethnic PGMs Presence 1981-2007

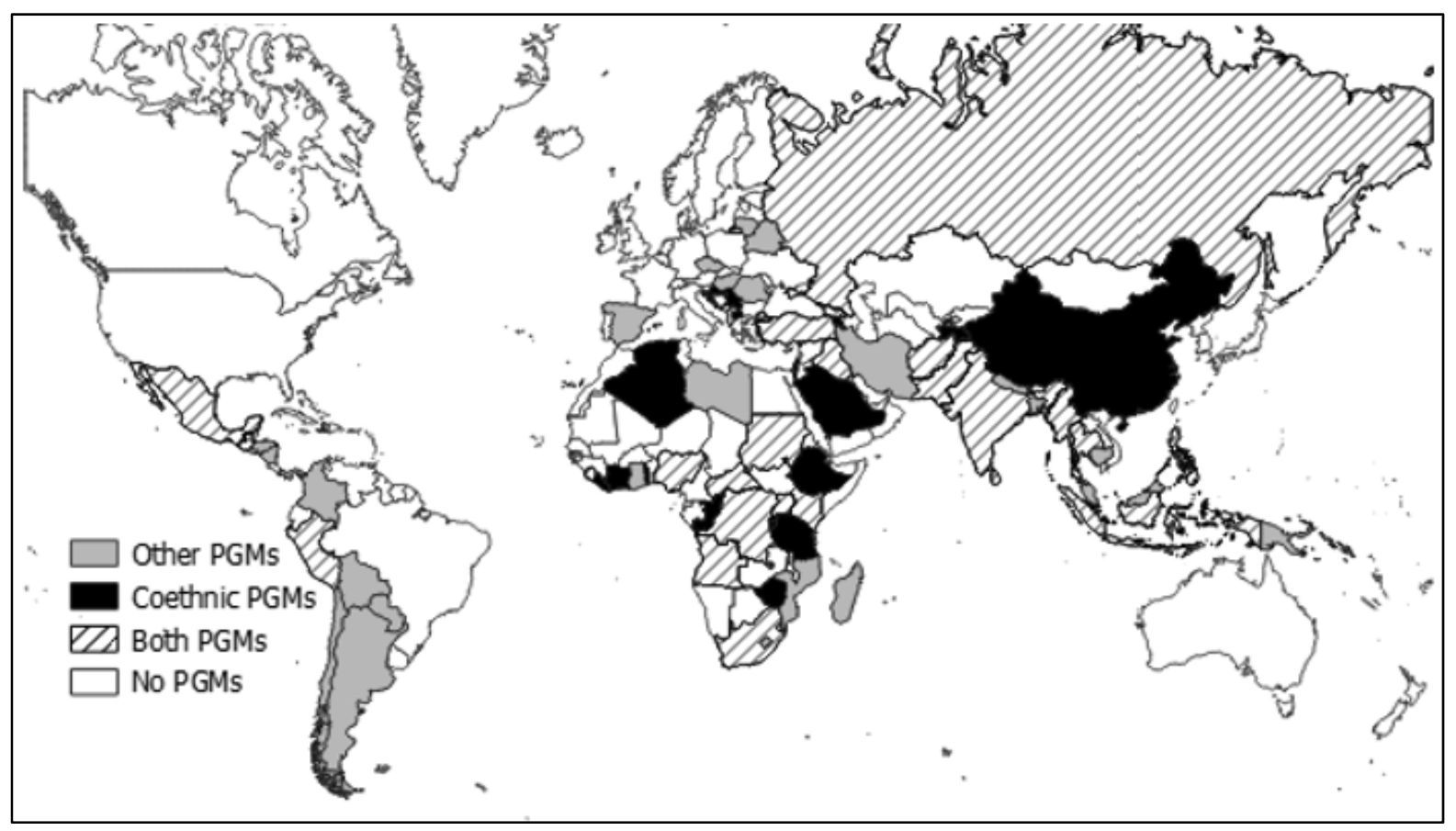

Data Structure and Modeling Approach

To assess the influence of co-ethnic PGMs on conflict intensity we draw on the UCDP Global events data (GED). Since the GED starts in 1989 and the PGM data is limited to 2007, our analysis focuses on the period 1989-2007. The fine-grain character of the GED and the dates of emergence in the PGM data allow us to disaggregate each conflict year into a count of 
conflict fatalities in each month. Our dataset includes 15615 conflict months, of which 51\% include the presence of a co-ethnic PGM. Since our dependent variable is a count of fatalities there is likely to be overdispersion in this data, we therefore use a negative binomial regression model in this analysis. ${ }^{8}$

To asses potential effects that co-ethnic PGMs have on conflict duration, we use a series of Cox proportional hazard models to estimate how co-ethnic and PGMs shape the hazard rate of conflict termination. For this analysis, our dependent variable is conflict termination (hazard). This is measured using the start and end date of a conflict in the UCDP data calculating the number of days from when a conflict meets the criteria to enter into the UCDP data, until the day it meets the criteria for termination (i.e. battle-related fatalities drops below 25 for at least a year) (Kreutz, 2010). This data consists of 501518 conflict days (unit of analysis) within 1,214 conflict years, of which there are 233 conflict terminations in total. ${ }^{9}$

\section{Controls}

To account for omitted variable bias, we include a number of control variables that relate to conflict duration and the emergence of pro-government militias. In particular, we account for key state characteristics, including regime type using the Polity IV measure (Marshall and Jaggers 2006), since instability and the proliferation of militias has been associated with states transitioning into democracy (Raleigh, 2016). We also include GDP per capita (Gleditsch 2002), to account for instability and state weakness where PGMs are likely to feature (Böhmelt and Clayton 2017; Carey and Mitchell, 2017; Jentzsch, Kalyvas and Schubiger, 2015).

We also account for key conflict characteristics, including controls for the presence of other conflicts, and whether the conflict is protracted (i.e. involved more than one episode of violence) (Gleditsch et al, 2002). We then control for whether the conflict is over territory or 
governmental control (Gleditsch et al, 2002). ${ }^{10}$ We also introduce controls accounting for rebel groups recruited along ethnic lines and that make ethnic claims, and the size of the ethnically discriminated population (Wucherpfennig et al, 2012). Since ethnic conflicts are generally prolonged and likely to involve greater violence, we explore the effect of PGMs independent from that of ethnic conflict. Finally, in the analysis on conflict intensity, we include temporal controls for battlefield violence (t-3), as previously violence can drive current intensity. We also control for the number of conflict months.

\section{Results}

Coethnic PGMs and Conflict Intensity

Hypothesis 1 suggested that co-ethnic militia are associated with high intensity violence. We assess this using negative binomial regression models and present the results on table 1 . Model 1 offers a baseline, including only our indicators of PGMs and controls for the duration of conflict and lagged count of fatalities. Model 2 then includes controls for conflict characteristics. As we expected, the co-ethnic militia variable reports a positive coefficient that is statistically significant in both models. To ensure that we are not simply picking up the effect of ethnic conflict, in model 3 we also control for the presence of ethnic insurgent groups and the size of the discriminated ethnic population. As hypothesized, conflict fought around ethnic cleavages is associated with high levels of civil violence, but this does not change the positive and significant effect of co-ethnic PGMs.

Table 1: Negative binomial regression models - Conflict Intensity 


\begin{tabular}{|c|c|c|c|c|c|}
\hline & (1) & (2) & (3) & (4) & (5) \\
\hline & Baseline & $\begin{array}{l}\text { Conflict } \\
\text { Controls }\end{array}$ & Full Sample & $\begin{array}{l}\text { Matched } \\
\text { Sample }\end{array}$ & $\begin{array}{l}\text { Matched } \\
\text { Sample }\end{array}$ \\
\hline Co-ethnic PGM (t-1) & $\begin{array}{l}0.347^{*} \\
(0.14)\end{array}$ & $\begin{array}{c}0.480^{* * *} \\
(0.11)\end{array}$ & $\begin{array}{l}0.367^{* 8} \\
(0.11)\end{array}$ & $\begin{array}{l}0.376^{* 8} \\
(0.132)\end{array}$ & $\begin{array}{l}0.445^{* 8} \\
(0.148)\end{array}$ \\
\hline Other PGM (t-1) & $\begin{array}{l}0.001 \\
(0.16)\end{array}$ & $\begin{array}{l}0.181 \\
(0.14)\end{array}$ & $\begin{array}{l}0.263+ \\
(0.149)\end{array}$ & $\begin{array}{c}0.257 \\
(0.158)\end{array}$ & $\begin{array}{c}0.227 \\
(0.152)\end{array}$ \\
\hline Incompatibility & & $\begin{array}{l}0.455^{* * *} \\
(0.13)\end{array}$ & $\begin{array}{l}0.834^{* * *} \\
(0.207)\end{array}$ & $\begin{array}{l}0.473^{* *} \\
(0.159)\end{array}$ & $\begin{array}{l}0.824^{* * *} \\
(0.199)\end{array}$ \\
\hline Parallel Conflicts & & $\begin{array}{l}-0.178^{8} \\
(0.08)\end{array}$ & $\begin{array}{c}-0.166^{* * *} \\
(0.077)\end{array}$ & $\begin{array}{l}-0.152+ \\
(0.087)\end{array}$ & $\begin{array}{l}-0.152^{8} \\
(0.076)\end{array}$ \\
\hline Protracted Conflict & & $\begin{array}{l}-0.201 \\
(0.15)\end{array}$ & $\begin{array}{l}-0.539^{* * *} \\
(0.182)\end{array}$ & $\begin{array}{l}-0.283 \\
(0.182)\end{array}$ & $\begin{array}{l}-0.449^{* *} \\
(0.191)\end{array}$ \\
\hline Polity2 & & $\begin{array}{l}-0.006 \\
(0.01)\end{array}$ & $\begin{array}{l}-0.009 \\
(0.18)\end{array}$ & $\begin{array}{l}-0.010 \\
(0.12)\end{array}$ & $\begin{array}{c}0.004 \\
(0.014)\end{array}$ \\
\hline GDP per capita (log) & & $\begin{array}{l}-0.000 \\
(0.00)\end{array}$ & $\begin{array}{l}0.009 \\
(0.01)\end{array}$ & $\begin{array}{c}0.000 \\
(0.000)\end{array}$ & $\begin{array}{c}0.000 \\
(0.000)\end{array}$ \\
\hline $\begin{array}{l}\text { Duration (number of } \\
\text { conflict months) }\end{array}$ & $\begin{array}{l}0.018^{* * *} \\
(0.01)\end{array}$ & $\begin{array}{l}0.015^{*} \\
(0.01)\end{array}$ & $\begin{array}{l}-0.000 \\
(0.00)\end{array}$ & $\begin{array}{c}0.013 \\
(0.008)\end{array}$ & $\begin{array}{l}0.0161^{*} \\
(0.007)\end{array}$ \\
\hline Lagged Fatalities t- 3 & $\begin{array}{l}0.002^{* * *} \\
(0.00)\end{array}$ & $\begin{array}{l}-0.201 \\
(0.15)\end{array}$ & $\begin{array}{l}0.007 \\
(0.01)\end{array}$ & $\begin{array}{l}0.002^{* * *} \\
(0.000)\end{array}$ & $\begin{array}{l}0.002^{* * *} \\
(0.000)\end{array}$ \\
\hline Discriminated pop & & & $\begin{array}{l}0.615 \\
(0.34)\end{array}$ & & $\begin{array}{c}0.480 \\
(0.366)\end{array}$ \\
\hline Ethnic Rebels & & & $\begin{array}{l}0.502^{* *} \\
(0.19)\end{array}$ & & $\begin{array}{l}0.535^{*} \\
(0.210)\end{array}$ \\
\hline Constant & $\begin{array}{c}2.833^{* * *} \\
(0.14)\end{array}$ & $\begin{array}{c}2.338^{* * *} \\
(0.29)\end{array}$ & $\begin{array}{l}1.681^{* * *} \\
(0.47)\end{array}$ & $\begin{array}{c}2.360^{* * *} \\
(0.367)\end{array}$ & $\begin{array}{l}1.443^{* 8} \\
(0.481)\end{array}$ \\
\hline Alpha & $\begin{array}{l}1.214^{* * *} \\
(0.12)\end{array}$ & $\begin{array}{c}1.154^{* * *} \\
(0.12)\end{array}$ & $\begin{array}{c}0.993^{* * *} \\
(0.14)\end{array}$ & $\begin{array}{c}0.979^{* * *} \\
(0.151)\end{array}$ & $\begin{array}{l}0.965^{* * *} \\
(0.152)\end{array}$ \\
\hline Log-Likelihood & -77444.309 & -65584.604 & -55322.185 & -48249.368 & -48177.915 \\
\hline No. of Obs. & 17852 & 15615 & 12564 & 11130 & 11130 \\
\hline
\end{tabular}

Robust Standard errors (clustered on conflict) in parentheses $\quad+p<0.10,{ }^{*} p<0.05,{ }^{* *} p<0.01,{ }^{* * *} p<0.001$

Statistical significance is important in evaluating variable effects, but we are also interested in the substantive impact of co-ethnic militia. For this purpose, we calculate marginal effects to assess the extent to which the presence of co-ethnic militia influences the predicted counts of fatalities during civil conflict, holding all other variables at their mean values. Across models 1-3, coethnic PGMs produce a significant increase of 14 to 17 fatalities per month, representing approximately a 19\% increase from the mean of 91 fatalities per month (see figure 2). 
Figure 2: Predicted Monthly Battlefield Deaths

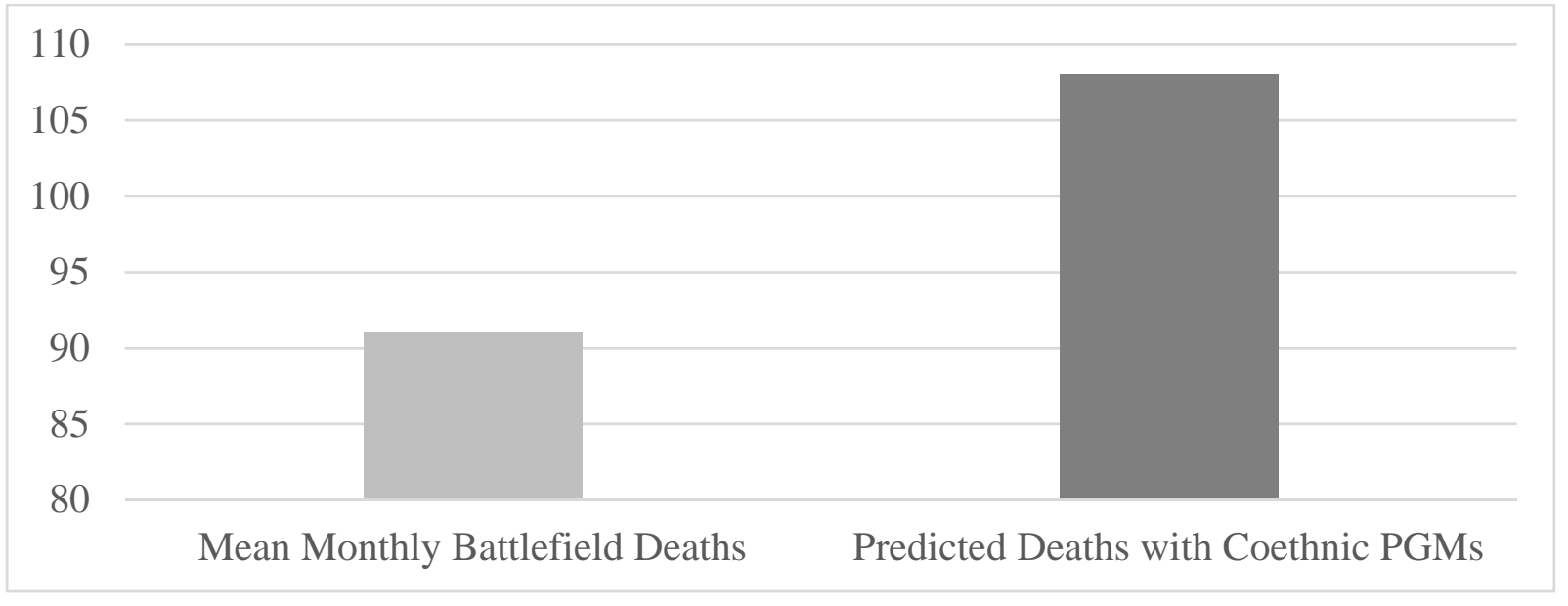

As we discuss above, co-ethnic militia could result from, rather than contribute to, high intensity violence. Whilst we do not discount the strategic calculations likely to motivate the co-option of co-ethnic PGMs, nor exclude the possibility that states facing high-intensity conflict might turn to co-ethnic militia, we account for this potential endogeneity by matching pair observations that featured a co-ethnic militia with similar observations without such a group. This removes observations without a co-ethnic militia that lack an analogue among the cases with a co-ethnic group (Ho et al. 2007). Pre-processing our data in this manner allows us to better assess the effect that co-ethnics produce independent of the conflict dynamics that might be more likely to produce such groups. We identify pairs using the MatchIt package in $\mathrm{R}$, adopting 1:1 nearest neighbour matching with replacement (Ho et al. 2006). This produces 5565 pairs of control and treatment observations from the original sample of 15615 conflict months.

Having matched our data we rerun models 2 and 3, presenting the results as models 4 and 5. The results remain positive and significant, and the marginal effects of co-ethnic produce and equivalent effect (i.e. increase the predicted monthly count of fatalities by 14 to 16 fatalities), offering further support for hypothesis 1 . 
Table 2: Negative binomial regression models - Conflict Intensity

\begin{tabular}{|c|c|c|c|c|c|}
\hline & (6) & (7) & (8) & (9) & (10) \\
\hline & Baseline & Full Sample & $\begin{array}{l}\text { Matched } \\
\text { Sample }\end{array}$ & $\begin{array}{c}\text { Full Sample } \\
\text { Reference } \\
\text { Category = } \\
\text { Other PGMs }\end{array}$ & $\begin{array}{c}\text { Matched Sample } \\
\text { Reference } \\
\text { Category = } \\
\text { Other PGMs }\end{array}$ \\
\hline Co-ethnic PGM (1) & $\begin{array}{l}0.395^{* 8} \\
(0.144)\end{array}$ & $\begin{array}{l}0.363^{* 8} \\
(0.116)\end{array}$ & $\begin{array}{l}0.438^{* 8} \\
(0.143)\end{array}$ & $\begin{array}{l}0.285+ \\
(0.172)\end{array}$ & $\begin{array}{l}0.412^{*} \\
(0.185)\end{array}$ \\
\hline Defector PGM (1) & $\begin{array}{l}-0.092 \\
(0.155)\end{array}$ & $\begin{array}{c}0.112 \\
(0.135)\end{array}$ & $\begin{array}{c}0.143 \\
(0.147)\end{array}$ & & \\
\hline Other ethnic PGM & $\begin{array}{c}0.360 \\
(0.234)\end{array}$ & $\begin{array}{c}0.211 \\
(0.219)\end{array}$ & $\begin{array}{c}0.446 \\
(0.296)\end{array}$ & & \\
\hline Non-ethnic PGM & $\begin{array}{l}-0.190 \\
(0.171)\end{array}$ & $\begin{array}{c}0.239 \\
(0.172)\end{array}$ & $\begin{array}{c}0.164 \\
(0.168)\end{array}$ & & \\
\hline Incompatibility & & $\begin{array}{l}0.874^{* * *} \\
(0.232)\end{array}$ & $\begin{array}{l}0.822^{* * *} \\
(0.222)\end{array}$ & $\begin{array}{l}0.658^{*} \\
(0.274)\end{array}$ & $\begin{array}{l}0.689^{*} \\
(0.287)\end{array}$ \\
\hline Parallel Conflicts & & $\begin{array}{l}-0.179^{8} \\
(0.0751)\end{array}$ & $\begin{array}{l}-0.161^{8} \\
(0.076)\end{array}$ & $\begin{array}{l}-0.223^{* *} \\
(0.076)\end{array}$ & $\begin{array}{l}-0.197^{*} \\
(0.078)\end{array}$ \\
\hline Protracted Conflict & & $\begin{array}{l}-0.564^{* *} \\
(0.186)\end{array}$ & $\begin{array}{l}-0.465^{8} \\
(0.195)\end{array}$ & $\begin{array}{l}-0.682^{* * *} \\
(0.207)\end{array}$ & $\begin{array}{l}-0.575^{* *} \\
(0.221)\end{array}$ \\
\hline Polity2 (1) & & $\begin{array}{c}0.012 \\
(0.012)\end{array}$ & $\begin{array}{l}0.00431 \\
(0.0135)\end{array}$ & $\begin{array}{c}0.006 \\
(0.014)\end{array}$ & $\begin{array}{l}-0.002 \\
(0.015)\end{array}$ \\
\hline GDP per capita (1) & & $\begin{array}{l}-0.000 \\
(0.000)\end{array}$ & $\begin{array}{c}0.000 \\
(0.000)\end{array}$ & $\begin{array}{l}-0.000 \\
(0.000)\end{array}$ & $\begin{array}{l}-0.000 \\
(0.000)\end{array}$ \\
\hline $\begin{array}{l}\text { Duration (number of } \\
\text { conflict months) }\end{array}$ & $\begin{array}{l}0.021^{* *} \\
(0.006)\end{array}$ & $\begin{array}{c}0.007 \\
(0.007)\end{array}$ & $\begin{array}{l}0.0174^{*} \\
(0.008)\end{array}$ & $\begin{array}{c}0.006 \\
(0.010)\end{array}$ & $\begin{array}{l}0.019^{*} \\
(0.009)\end{array}$ \\
\hline Lagged Fatalities t-3 & $\begin{array}{l}0.002^{* * *} \\
(0.004)\end{array}$ & $\begin{array}{l}0.002^{* * *} \\
(0.000)\end{array}$ & $\begin{array}{l}0.002^{* * *} \\
(0.000)\end{array}$ & $\begin{array}{l}0.002^{* * *} \\
(0.000)\end{array}$ & $\begin{array}{l}0.002^{* * *} \\
(0.000)\end{array}$ \\
\hline Discriminated pop & & $\begin{array}{l}0.709^{*} \\
(0.361)\end{array}$ & $\begin{array}{c}0.470 \\
(0.420)\end{array}$ & $\begin{array}{c}0.416 \\
(0.423)\end{array}$ & $\begin{array}{c}0.246 \\
(0.511)\end{array}$ \\
\hline Ethnic Rebels & & $\begin{array}{l}0.521^{*} \\
(0.227)\end{array}$ & $\begin{array}{l}0.509^{*} \\
(0.228)\end{array}$ & $\begin{array}{l}0.611^{* *} \\
(0.225)\end{array}$ & $\begin{array}{l}0.703^{*} \\
(0.282)\end{array}$ \\
\hline Constant & $\begin{array}{l}2.816^{* * *} \\
(0.145)\end{array}$ & $\begin{array}{l}1.634^{* 8} \\
(0.537)\end{array}$ & $\begin{array}{l}1.474^{* 8} \\
(0.515)\end{array}$ & $\begin{array}{c}2.473^{* * *} \\
(0.591)\end{array}$ & $\begin{array}{l}1.985^{* 8} \\
(0.655)\end{array}$ \\
\hline Alpha & $\begin{array}{l}1.208^{* * *} \\
(0.114)\end{array}$ & $\begin{array}{l}0.992^{* * *} \\
(0.137)\end{array}$ & $\begin{array}{c}0.963^{* * *} \\
(0.151)\end{array}$ & $\begin{array}{c}0.883^{* * *} \\
(0.145)\end{array}$ & $\begin{array}{c}0.824^{* * *} \\
(0.165)\end{array}$ \\
\hline Log-Likelihood & -77393.07 & -55317.271 & -48164.362 & -42587.256 & -35447.83 \\
\hline No. of Obs. & 15615 & 12564 & 11130 & 9217 & 7786 \\
\hline
\end{tabular}

The results thus far indicate that conflict months are more violent when co-ethnic PGMs are present. However, this effect could be driven simply by the presence of PGMs. While models 2 through 5 control for other forms of militia, this does not assess the influence of co-ethnics 
PGMs relative to other PGM. We therefore divide the "other" militia category, and rerun the analysis including two variables for other ethnic PGMs: defectors, other ethnic PGMs, and non-coethnic PGMs. Finally, we also control for non-ethnic PGMs. We present the results for the baseline sample in model 6, followed by the full sample in model 7 and the matched sample in model 8. We find further evidence that co-ethnic militia are associated with higher levels of violence, and also find that this effect is not extended to other forms of PGM.

To assess this difference statistically, we next limit our sample to conflict months in which militias are present, and rerun the analysis comparing the effect of co-ethnic militia to other forms of PGM. In essence, the coefficient for the co-ethnic militia variable in models 9 and 10 indicates the effect of co-ethnic PGMs relative to all other militias. The marginal effects suggest that co-ethnic PGMs increase the number of fatalities by between 14 (model 9) and 17 (model 10) per month. This suggests that co-ethnic militia, relative to other forms of PGM, are more likely to be associated with greater civil violence.

To assess the robustness of our findings we changed a number of model specifications and reran the estimates. We present these results in an accompanying online appendix (OA). While using conflict months allows us to utilize fine-grain conflict event data and specific dates capturing militia emergence, it could be argued that this approach inflates our sample by artificially creating additional observations. As a result, we first rerun our analysis using conflict years (Table OA1). The results remain consistent.

Next, we lag the independent variables to ensure causal ordering between active militias and levels of armed violence. However, when operating at the monthly level this is less of a risk, and might bias our results. We therefore rerun the analysis without lagging any variables. The results remain consistent (Table OA2). 
In our analysis we opt for a parsimonious model focusing on the factors most likely to influence conflict intensity. However, there are other factors that might influence the intensity of a dispute and/or the presence of PGMs. We therefore rerun the analysis including a number of other possible cofounders (Table OA2). First, we account for other opportunity-based factors (i.e. Buhaug, Gates, and Lujala 2009), and include measures capturing the percentage of mountainous territory, drug production, hydrocarbon extraction, gemstone extraction, whether the conflict zone borders another state, and the number of contiguous states. Second, we account for international mediators (DeRouen, Bercovitch and Pospieszna, 2011), and peacekeeping (Hegre, Hultman and Nygard, 2015). Third, to account for the relative fighting capacity of the disputants we include an indicator measuring the relative capacity of the rebel force (Cunningham, 2006). Finally, we control for decentralization and whether a state has a federal system which has been related to the pacification of ethnic disputes and may reduce conflict intensity (Cederman et al., 2015). In all cases our results remain consistent.

Whilst our results suggest a strong association between co-ethnics and conflict intensity, we return to potential interceding effects of ethnic conflict. We divide our sample into ethnic and non-ethnic conflict, defined by the presence of ethnic rebels (Table OA3). The effect of co-ethnic militias is positive for both. As previously argued, this suggests that coethnic militia relate to ethnic politics more broadly, are not limited to conflict between ethnic groups and influence conflict dynamics through multiple mechanisms. While our results suggest ethnic PGMs do exacerbate ethnic divisions, our findings extend to non-ethnic conflict, offering further validation of our arguments relating to the recruitment and loyalty advantages offered by co-ethnic PGMs.

To ensure that our findings are not driven by conflict months with particularly extreme levels of violence, we limit our analysis to exclude months with more than 5000 (4 months), 
3000 (21 months), 2000 (45 months) and 1000 (164 months) deaths. Next we run jackknife estimations to account for potential outliers; control for the number of co-ethnic PGMs, as countries with more PGMs may be driving the results; and control for cases where co-ethnic PGMs are active prior to the conflict (Table OA4). In all cases the results remain consistent.

We do not include fixed effects in the prior analysis because of the low level of withincase variation on our partially time invariant explanatory variable, which can eliminate "too much” cross-sectional variance and severely bias our estimates (Plumper, Troeger, and Manow 2005, 330-34). However, as an additional check we run the analysis including country as well as random effects. The results show a consistent effect of co-ethnic militias (Table OA5).

Next, we account for whether different temporal lags and model choice is driving our results (Table OA6). We use shorter (t-1) and longer time lags (t-6, t-12, t-12 sq) and use a OLS regression model, with a logged DV, as an alternative to our negative binomial models with a highly skewed DV with many zeros. Our results remain the same.

Finally, whilst it is clearly important to control for the effect of other militia groups, including co-ethnic and other militias in the same model risks introducing bias through autocorrelation. As such, we adopt an alternative approach, including two dummy variables measuring the presence of any PGM (including co-ethnic) and co-ethnic PGM. In this set up, the co-ethnic variable effectively represents an interaction term, showing the conditional effect of co-ethnic relative to other PGMs. ${ }^{11}$ Once again only co-ethnic PGMs are shown to have a significant conflict enhancing effect. ${ }^{12}$ Taken together, we therefore find strong support for hypothesis 1. 
Hypothesis 2 predicted that co-ethnic PGMs are associated with longer civil conflicts. States drawing on co-ethnic groups are expected to be more resilient to rebel threats, which is likely to produce longer conflicts. We assess these claims using Cox proportional hazard models in which conflict termination is the baseline hazard. To ensure first ordering, we lag time-varying covariates by one year ( $t-1)$, and cluster the standard errors by conflict to address possible dependency in conflict episodes. For ease of interpretation we report coefficient estimates rather than the hazard ratios; negative coefficients indicate a lower likelihood of termination, and thus longer expected duration, while positive signs indicate a higher probability of termination and thus shorter conflicts.

We adopt a similar set up to the prior analysis. In model 11, we show the baseline model, then include key conflict characteristics (model 12) and include additional controls to account for ethnic conflict (model 13). As we are no longer limited by the temporal span of the Uppsala GED data, we expand our analysis to the full period covered by the PGM database (1981-2007). As such, we include an additional controls to account for the post-Cold War period and for conflict intensity which was not needed in the prior analysis.

The results offer strong support for hypothesis 2 . In both models the co-ethnic militia variable shows the expected negative impact, indicating a reduction in the likelihood of termination, and thus longer duration. Co-ethnic PGMs have a notable and significant effect, reducing the baseline hazard (likelihood of termination) by between 40 and $62 \%$ in our full sample.

Table 3: Cox Proportional Hazard Models: EPGMs, and Conflict Duration 


\begin{tabular}{|c|c|c|c|c|c|}
\hline & (11) & (12) & (13) & (14) & (15) \\
\hline & Baseline & $\begin{array}{c}\text { Full } \\
\text { Sample }\end{array}$ & Full Sample & $\begin{array}{c}\text { Matched } \\
\text { Sample }\end{array}$ & $\begin{array}{c}\text { Matched } \\
\text { Sample }\end{array}$ \\
\hline Co-ethnic PGM (t-1) & $\begin{array}{l}-0.479^{* *} \\
(0.150)\end{array}$ & $\begin{array}{l}-0.403^{*} \\
(0.192)\end{array}$ & $\begin{array}{l}-0.616^{* *} \\
(0.212)\end{array}$ & $\begin{array}{l}-0.680^{* *} \\
(0.245)\end{array}$ & $\begin{array}{l}-0.694^{* *} \\
(0.250)\end{array}$ \\
\hline Other PGM (t-1) & $\begin{array}{l}-0.371 \\
(0.142)^{8 *}\end{array}$ & $\begin{array}{l}-0.138 \\
(0.194)\end{array}$ & $\begin{array}{l}-0.327 \\
(0.218)\end{array}$ & $\begin{array}{l}-0.411^{+} \\
(0.229)\end{array}$ & $\begin{array}{l}-0.410^{+} \\
(0.228)\end{array}$ \\
\hline Incompatibility & & $\begin{array}{c}0.017 \\
(0.171)\end{array}$ & $\begin{array}{l}-0.034 \\
(0.207)\end{array}$ & $\begin{array}{l}-0.110 \\
(0.200)\end{array}$ & $\begin{array}{l}-0.113 \\
(0.210)\end{array}$ \\
\hline Parallel Conflicts & & $\begin{array}{l}-0.026 \\
(0.067)\end{array}$ & $\begin{array}{c}0.001 \\
(0.072)\end{array}$ & $\begin{array}{c}0.030 \\
(0.073)\end{array}$ & $\begin{array}{c}0.032 \\
(0.076)\end{array}$ \\
\hline Protracted Conflict & & $\begin{array}{l}-0.320^{+} \\
(0.179)\end{array}$ & $\begin{array}{l}-0.279 \\
(0.198)\end{array}$ & $\begin{array}{l}-0.255 \\
(0.200)\end{array}$ & $\begin{array}{l}-0.260 \\
(0.209)\end{array}$ \\
\hline $\begin{array}{l}\text { Conflict Intensity (log } \\
\text { t-1) }\end{array}$ & & $\begin{array}{l}-0.269^{* *} \\
(0.070)\end{array}$ & $\begin{array}{l}-0.223^{* *} \\
(0.075)\end{array}$ & $\begin{array}{l}-0.253^{* *} \\
(0.073)\end{array}$ & $\begin{array}{l}-0.256^{* *} \\
(0.075)\end{array}$ \\
\hline Polity2 Squared (t-1) & & $\begin{array}{c}-0.003 \\
(0.003)\end{array}$ & $\begin{array}{l}-0.001 \\
(0.003)\end{array}$ & $\begin{array}{c}0.000 \\
(0.003)\end{array}$ & $\begin{array}{c}0.001 \\
(0.003)\end{array}$ \\
\hline GDP per capita (log t-1) & & $\begin{array}{l}-0.000^{+} \\
(0.000)\end{array}$ & $\begin{array}{l}-0.000 \\
(0.000)\end{array}$ & $\begin{array}{l}-0.000 \\
(0.000)\end{array}$ & $\begin{array}{l}-0.000 \\
(0.000)\end{array}$ \\
\hline Post-Cold War & & $\begin{array}{l}1.388^{* 8} \\
(0.307)\end{array}$ & $\begin{array}{l}1.732^{* 8} \\
(0.359)\end{array}$ & $\begin{array}{l}1.603^{* 8} \\
(0.356)\end{array}$ & $\begin{array}{l}1.629^{* 8} \\
(0.371)\end{array}$ \\
\hline Discriminated pop & & & $\begin{array}{c}0.177 \\
(0.501)\end{array}$ & & $\begin{array}{c}0.195 \\
(0.513)\end{array}$ \\
\hline Ethnic Rebels & & & $\begin{array}{c}0.001 \\
(0.243) \\
\end{array}$ & & $\begin{array}{c}-0.003 \\
(0.249)\end{array}$ \\
\hline No. of Obs. & 933 & 933 & 839 & 784 & 784 \\
\hline Conflict Terminations & 181 & 181 & 162 & 156 & 156 \\
\hline $\begin{array}{l}\text { No. Days at Risk } \\
\text { Log-Likelihood }\end{array}$ & $\begin{array}{l}395816 \\
-1090.924\end{array}$ & $\begin{array}{l}395816 \\
-749.817\end{array}$ & $\begin{array}{l}364005 \\
-641.017\end{array}$ & $\begin{array}{c}382914 \\
-628.72974\end{array}$ & $\begin{array}{c}382914 \\
-628.66216\end{array}$ \\
\hline
\end{tabular}

Coefficients Reported. Robust Standard errors (clustered on conflict) in parentheses $+p<0.10,{ }^{*} p<0.05,{ }^{* *} p<0.01,{ }^{* * *} p<0.001$

However, our full sample findings do not discount the possibility that there is something fundamentally different about the cases in which co-ethnic militia are used, which both leads to the production of co-ethnic PGMs, and the longer duration. We were unable to identify a suitable instrument to isolate the independent effect of co-ethnic groups, so again account for observable factors using matching. Adopting 1:1 nearest neighbour matching with replacement (Ho et al. 2007) produces 393 pairs of control and treatment observations. As models 14 and 15 show, our analysis of the matched dataset adds further support for our hypotheses as co- 
ethnic PGMS produce a strong and significant effect in the direction we predicted. This adds further support to our theoretical claims and helps to address confounding explanations related to endogeneity.

Figure 2: Kaplan-Meier survivor function- Model 12

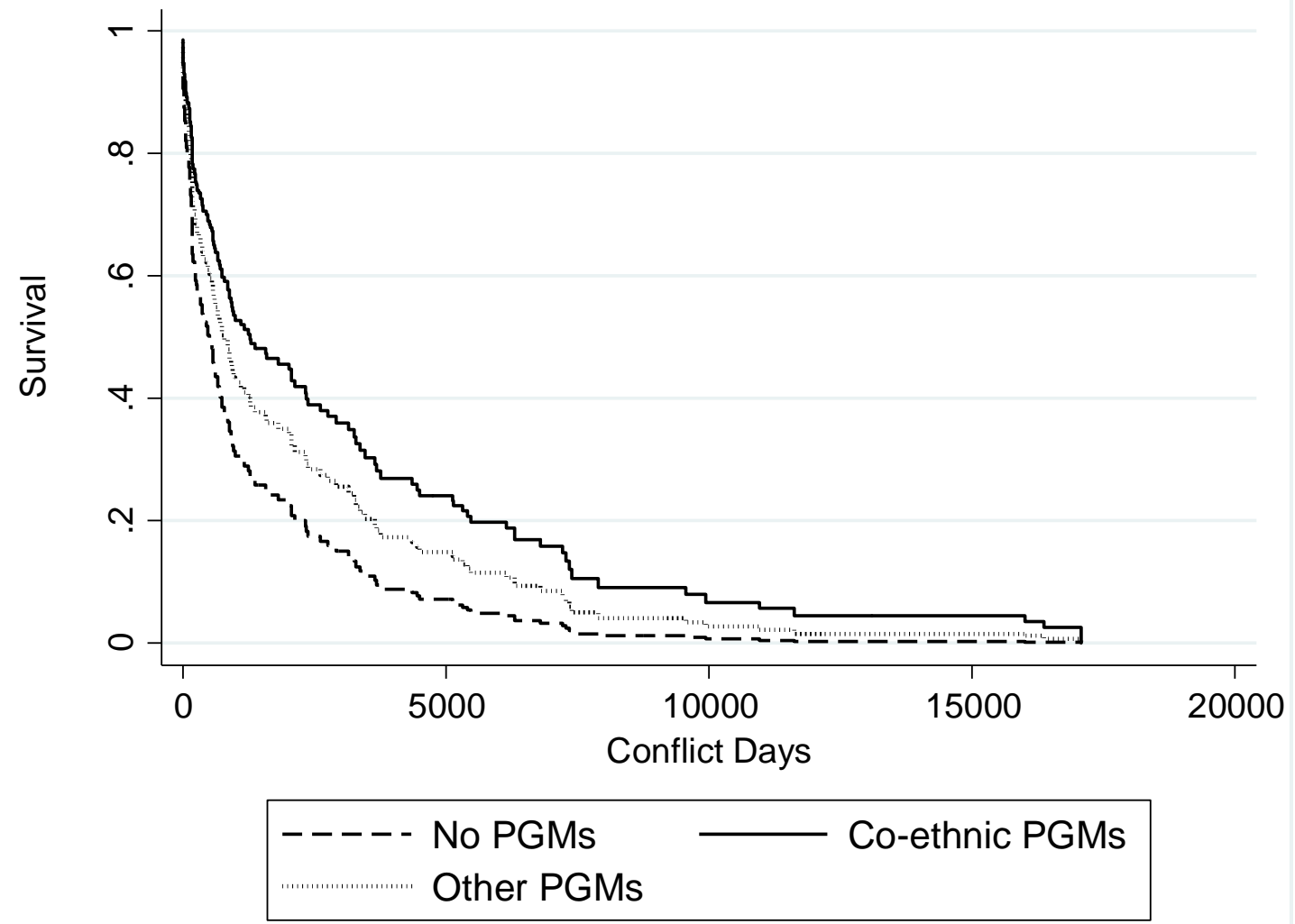

To visualize these effects, figure 2 presents the Kaplan-Meier predicted survivor function (yaxis). The co-ethnic PGMs line is consistently higher than the no-PGMs line across the entire conflict lifecycle, in which cases with conflicts are on average more $20 \%$ likely to endure when co-ethnic PGMs are active when compare to conflicts without PGMs. The biggest impacts are in the earlier stages of conflict. For instance, in the third year of a civil conflict (or 1,095 days), the likelihood of conflict continuing is $30 \%$ higher when co-ethnic PGMs are present than conflicts containing no PGMs, and 20\% higher when compared to conflicts with other PGMs.

Table 4: Cox Proportional Hazard Models: EPGMs, and Conflict Duration 


\begin{tabular}{|c|c|c|c|c|c|}
\hline & (16) & (17) & (18) & (19) & (20) \\
\hline & Baseline & $\begin{array}{c}\text { Full } \\
\text { Sample }\end{array}$ & $\begin{array}{l}\text { Matched } \\
\text { Sample }\end{array}$ & $\begin{array}{c}\text { Full Sample } \\
\text { Reference } \\
\text { Category = } \\
\text { Other PGMs }\end{array}$ & $\begin{array}{c}\text { Matched Sample } \\
\text { Reference } \\
\text { Category = } \\
\text { Other PGMs }\end{array}$ \\
\hline Co-ethnic PGM (t-1) & $\begin{array}{l}-0.488^{* * * *} \\
(0.153)\end{array}$ & $\begin{array}{l}-0.605^{* * * *} \\
(0.209)\end{array}$ & $\begin{array}{c}-0.605^{* *} \\
(0.249)\end{array}$ & $\begin{array}{c}-0.581 * * \\
(0.238)\end{array}$ & $\begin{array}{c}-0.557 * * \\
(0.275)\end{array}$ \\
\hline Defector PGM (t-1) & $\begin{array}{l}0.0349 \\
(0.182)\end{array}$ & $\begin{array}{l}-0.026 \\
(0.221)\end{array}$ & $\begin{array}{l}-0.121 \\
(0.231)\end{array}$ & & \\
\hline Other Ethnic PGM (t-1) & $\begin{array}{l}-0.655 \\
(1.004)\end{array}$ & $\begin{array}{l}-0.747 \\
(1.194)\end{array}$ & $\begin{array}{l}-0.705 \\
(1.189)\end{array}$ & & \\
\hline Non-ethnic PGMs (t-1) & $\begin{array}{l}-0.197 \\
(0.147)\end{array}$ & $\begin{array}{l}-0.098 \\
(0.199)\end{array}$ & $\begin{array}{l}-0.090 \\
(0.206)\end{array}$ & & \\
\hline Incompatibility & & $\begin{array}{l}-0.0242 \\
(0.203)\end{array}$ & $\begin{array}{l}0.0126 \\
(0.206)\end{array}$ & $\begin{array}{l}-0.306 \\
(0.265)\end{array}$ & $\begin{array}{l}-0.203 \\
(0.271)\end{array}$ \\
\hline Parallel Conflicts & & $\begin{array}{l}-0.022 \\
(0.069)\end{array}$ & $\begin{array}{l}-0.018 \\
(0.076)\end{array}$ & $\begin{array}{c}0.009 \\
(0.078)\end{array}$ & $\begin{array}{c}0.017 \\
(0.087)\end{array}$ \\
\hline Protracted Conflict & & $\begin{array}{l}-0.288 \\
(0.194)\end{array}$ & $\begin{array}{l}-0.287 \\
(0.206)\end{array}$ & $\begin{array}{l}-0.223 \\
(0.238)\end{array}$ & $\begin{array}{l}-0.226 \\
(0.255)\end{array}$ \\
\hline $\begin{array}{l}\text { Conflict Intensity (log } \\
\text { (t-1) }\end{array}$ & & $\begin{array}{l}-0.218 * * * \\
(0.0751)\end{array}$ & $\begin{array}{l}-0.195 * * * \\
(0.0748)\end{array}$ & $\begin{array}{l}-0.356 * * * \\
(0.102)\end{array}$ & $\begin{array}{l}-0.335 * * * \\
(0.104)\end{array}$ \\
\hline Polity2 Squared (t-1) & & $\begin{array}{l}-0.001 \\
(0.004)\end{array}$ & $\begin{array}{l}-0.000 \\
(0.003)\end{array}$ & $\begin{array}{l}-0.010^{*} \\
(0.005)\end{array}$ & $\begin{array}{c}-0.011 * * \\
(0.005)\end{array}$ \\
\hline $\begin{array}{l}\text { GDP per capita (log } \\
\mathrm{t}-1 \text { ) }\end{array}$ & & $\begin{array}{l}-0.000 \\
(0.000)\end{array}$ & $\begin{array}{l}-0.000 \\
(0.000)\end{array}$ & $\begin{array}{l}-0.000 * * \\
(0.000)\end{array}$ & $\begin{array}{l}-0.000^{*} \\
(0.000)\end{array}$ \\
\hline Post-Cold War & & $\begin{array}{l}1.767 * * * \\
(0.370)\end{array}$ & $\begin{array}{l}1.741^{* * * *} \\
(0.392)\end{array}$ & $\begin{array}{l}2.597 * * * * \\
(0.505)\end{array}$ & $\begin{array}{l}2.525^{* * * *} \\
(0.537)\end{array}$ \\
\hline Discriminated pop & & $\begin{array}{c}0.161 \\
(0.488)\end{array}$ & $\begin{array}{c}0.224 \\
(0.486)\end{array}$ & $\begin{array}{c}0.672 \\
(0.635)\end{array}$ & $\begin{array}{c}0.644 \\
(0.636)\end{array}$ \\
\hline Ethnic Rebels & & $\begin{array}{l}0.0238 \\
(0.239) \\
\end{array}$ & $\begin{array}{l}0.0510 \\
(0.254) \\
\end{array}$ & $\begin{array}{l}-0.327 \\
(0.291) \\
\end{array}$ & $\begin{array}{l}-0.260 \\
(0.314) \\
\end{array}$ \\
\hline No. of Obs. & 933 & 839 & 784 & 711 & 657 \\
\hline Conflict Terminations & 181 & 162 & 156 & 106 & 100 \\
\hline No. Days at Risk & 395816 & 364005 & 335240 & 321472 & 293072 \\
\hline Log-Likelihood & -1093.4191 & -642.1120 & -610.1101 & -360.8033 & -332.7614 \\
\hline
\end{tabular}

Coefficients Reported. Robust Standard errors (clustered on conflict) in parentheses

$+p<0.10,{ }^{*} p<0.05,{ }^{* *} p<0.01,{ }^{* * *} p<0.001$

AS with the prior analysis it is important to check whether the relationship we observe, between co-ethnic PGMs and civil war duration, is not driven by the mere presence of PGMs. Again we disaggregate the “other” military category into: defectors, other ethnic PGMs and non-coethnic PGMs. Models 16-18 provide further evidence that co-ethnic PGMs increase the duration of civil war. We find no such evidence for other forms of PGM. We then limit our sample to only 
conflict years in which PGMs are present, which compares co-ethnic PGMs with all other PGMs. Models 19-20 show that co-ethnic PGMs are more likely to be associate with prolonged conflict than other types of PGM.

The control variables behave largely as expected. Conflicts are shorter in the post-Cold War period and conflicts are likely to be longer with higher intensity, which is often associated with ethnic actors (Eck, 2009). Regime type and GDP have no significant effect. Finally, and most surprisingly, we find little evidence that the number of parallel conflicts or ethnic rebels increase the duration of civil war, despite fragmentation and ethnically mobilized rebels previously being shown to increase conflict duration.

To ensure the robustness of our findings we again change a number of specifications. Firstly, we included a number of additional controls to ensure our results are not driven by omitted variables. One challenge is that weak state capacity might explain both to the use of co-ethnic PGM and longer conflicts. In our main analyses we proxy for this using GDP per capita. To explore this further we add additional variables (Hendrix and Young, 2014): state capacity, generated using a factor analysis of International Country Risk Guide variables (bureaucracy quality, and law and order), and military capacity, also derived from a factor analysis (combines military personnel, military expenditures, and military expenditures per soldier). The results remain consistent (Table OA7), offering further evidence that co-ethnics have an effect independent of the weak contexts where they are likely to emerge in.

Another alternative explanation might be that our co-ethnic PGM variable is capturing effects an ethno-political context that are related to the emergence of ethnic PGMs and durable civil war. We account for this in our model, but here include additional measures including the size of the ethnically excluded population and the largest excluded group (Wucherpfennig et al, 2012). Across both analyses, the co-ethnic militia are the only indicator of ethnicity with 
consistent conflict-enhancing effects (Table OA7). This suggests that whilst political exclusion increases the likelihood of civil conflict, we find little evidence of its conflict-enhancing effect. We then control for federalism, which can reduce the duration of disputes that are underway. Our results do not change.

Thirdly, whilst EPGMs operate in many continents, ethnicity is most often associated with African conflicts, which also tend to be longer. To ensure our results are not limited to a specific region we include a series of regional controls and conduct jackknife estimations to account for possible outliers (Cunningham, Gleditsch, and Salehyan, 2009). Moreover, we change the specification to cluster standard errors by conflict episodes and then by country (instead of by conflict). In all cases the results remain consistent (Table OA8).

We then explore other alternative explanations. First, the role of opportunity factors including resources and favourable geographic conditions that have previously been shown to influence a rebel group’s ability to sustain conflict (Buhaug, Gates, and Lujala 2009), whilst also motivating the creation of a PGM force. Here we include additional controls for the presence of lootable gemstones, oil, mountainous terrain in the conflict zone, and the distance from the conflict zone to the capital and nearest border. Second, we account for more capable rebel organisations (Cunningham, Gleditsch, and Salehyan, 2009) and relative rebel strength in relation to the government. The results further support our findings (Table OA9).

Next we explore whether modelling assumptions are responsible for the results (also Table OA9). The Cox model we use allows the inclusion of covariates of survival times, but has less restrictive assumptions than the Weibull model. Yet, our results remain the same when rerun the analysis with a Weibull model. Next we use a logit model to assess the influence of EPGMs on conflict termination. Our measure of co-ethnic PGM performs consistently well. The co-ethnic variable produces a 50\% reduction in the likelihood of termination when all other 
variables are held constant. In-sample analysis reveals that removing the co-ethnic variable significantly reduces the predictive power (Figure OA1). Next, we explore the possibility that our measure of conflict duration is driving the results. Gates and Strand (2004) show that different measures can produce dissimilar results. We run the analysis with an alternative calculation of conflict duration - the number of civil war months, and then years. The results are consistent regardless of how we calculate duration.

Finally, it could be that co-ethnic PGMs are an endogenous feature of conflict duration. States might turn to EPGMs as reinforcements in a long drawn-out conflict. We do not totally discount the possibility that states turn to militias later in a dispute, ${ }^{13}$ as our theory predicts that co-ethnic PGMs increase state resilience, which could be required early or late in a conflict. If it were the case, we would expect to observe relatively fewer co-ethnic militia in earlier years of a conflict than in later years. This is not what we see in the data, since co-ethnic PGMs are active in all stages of a conflict lifespan. Relatively speaking, co-ethnic PGMs appear in 36\% of conflicts in the year of onset, increases steadily to a high of $59 \%$ of conflict in their eighth year and then remaining largely stable around 50\% of conflicts in subsequent years (see Figure OA2). Moreover, the initial perceived increase in co-ethnic PGMS appears to be driven by a reduction in conflicts that do not include co-ethnic EPGMs, rather than the later introduction of new PGMs. We explore this further by assessing the impact of co-ethnic PGMs on conflict termination at five-year intervals using logit models (Table OA10). Across all periods (years 0-5, 5-10, 10-15 and 15-20) co-ethnic PGMs are consistently related to a lower likelihood of conflict termination. Moreover, when comparing subset cases where co-ethnic PGMs were active prior to conflict with those active during conflict, we find that both have an impact on the longer duration of armed conflict, with the coefficient slightly stronger for coethnic PGMs that mobilize prior to the conflict. This further alleviates concerns of endogeneity. 


\section{Conclusion}

In this article, we argue that PGMs recruited along co-ethnic lines have a previously overlooked influence on conflict dynamics. States facing internal challenges often turn to coethnic militia that are quickly mobilized as loyal force multipliers. We show that the presence of co-ethnic PGMs is often associated with more intense and longer civil wars compared to other forms of ethnic and non-ethnic PGMs. We argue that this is a result of a combination of factors. First, the strong relationship between the state and co-ethnic groups provides the state with a loyal fighting force and enhances the state's capacity to resist insurgent challenges. Second, despite the loyalty of co-ethnic groups to the state, such irregular forces are often less accountable than official armed forces, can pose higher risks to civilians and have incentives to undermine peacemaking attempts that could compromise their ethnic group's privileged status. Third, because co-ethnic PGMs are usually deployed against insurgents made up of an excluded ethnic group, co-ethnic PGMs play a significant role in increasing inter-ethnic polarization and ethnic extremism. We find support for these arguments in a statistical analysis using new data, which for the first time, captures the ethnic affiliations of PGMs across a global sample of cases from 1981-2007.

This study makes a contribution to our understanding of how state-military relations influence conflict dynamics, in particular concerning PGMs. A collection of work has begun to explore the effects that PGMs have inside and outside of civil war, but has until now overlooked the role of ethnicity. Similarly, while the civil war literature has advanced in showing how conflict intensity and duration are shaped by the ethnic character of insurgents, and the distribution of power across ethnic groups, this work has until now missed the important effect of co-ethnic PGMs (Eck, 2009; Cederman, Gleditsch, and Buhaug, 2013; Wucherpfennig et al 2012). Conventional wisdom currently holds that PGMs more generally (i.e. non-ethnic militias) can have adverse effects because states lose control of or are unwilling 
to control their agents. By bringing together principal-agent theory and ethnic grievances arguments, we demonstrate that the ethnic ties that bind a PGM to those in power can have adverse effects, in which co-ethnic PGMs insulate incumbents from challengers but simultaneously exacerbate inter-ethnic tensions.

Our findings also have important implications for the policy community. In Iraq, for example, our findings suggest that the Shia-dominated militias used to repel the ISIS advance are likely to act as a serious impediment to peace. A challenge for the Iraqi government will be to find ways to reign in Shia militia or incorporate them into official military structures. Future research could, for example, examine the conditions in which co-ethnic PGMs are more likely to disarm. Similarly, our analysis suggests that co-ethnic PGMs operating in the Philippines might undermine the bargaining process with Muslim rebels in Mindanao. Determining how to incorporate co-ethnic PGMs into a peace process would be another important and timely extension of this research. 


\section{Notes}

${ }^{1}$ Also see Wucherpfennig et al (2012) and Cederman, Gleditsch, and Buhaug (2013) on the 'logic of ethno-political exclusion'.

${ }^{2}$ For a full list of cases, see online appendix (Table OA11).

3 The requirement of political relevance excludes groups whose membership is based on localized group ties rather than a clear ethnic identity. This excludes regionally defined groups that do not meet the threshold of an ethnic identity such as the post-independence death squads in East-Timor.

${ }^{4}$ We provide evidence and sources for each PGM that we code.

${ }^{5}$ Our approach is akin to that used in the ACD2EPR dataset. Some PGMs have linkages with multiple groups, and some ethnic constituencies link to multiple PGMs. For example, we code the Kebele militia in Ethiopia as a co-ethnic PGM as it is composed of a coalition of ethnic groups that share power, whereas the multi-ethnic Basij militia in Iran is not, as it recruits on ideological lines. In Sudan, while many Arab militias are recruited from a different tribe to those in power, we code them as co-ethnic based on shared Arab identity.

${ }^{6}$ Following the EPR data, political power relates to control over the presidency, cabinet, or senior posts within the executive.

${ }^{7}$ Unlike the PGM dataset, the recently released African Relational Pro Government Militia Dataset (RPGMD) (Magid and Schon 2018) is limited to African years after 1997.

${ }^{8}$ Likelihood ratio tests confirm that our data is overdispersed and thus the negative-binomial model is the appropriate choice.

${ }^{9}$ Introducing all control variables reduces the number of observations to 839 country years and 162 failures. Conflicts where no conflict termination occurs by 2007 are removed as they do not have the opportunity to "fail".

${ }^{10}$ A summary of these variables is included in the appendix.

${ }^{11}$ Including a variable measuring the presence of PGMs and interacting this with a variable capturing the presence of co-ethnic PGMs is not possible as there are no cases in which co- 
ethnic PGMs are present without PGMs. The interaction term will always be dropped from the analysis due to collinearity.

${ }^{12}$ We also replicate all of our robustness checks using this specification, and the all results remain consistent.

${ }^{13}$ Kalyvas (2008) argues that defection to the government side is more common in later stages of rebellion. 


\section{References}

Alden, C., Thakur, M., and Arnold, M.W. 2011. Militias and the Challenges of Post-conflict Peace: Silencing the Guns. Chicago: Chicago University Press.

Aliyev, H. 2018. “'No Peace, No War’ Proponents? How Pro-Regime Militias affect Civil War Termination and Outcomes.” Cooperation and Conflict. Online first.

Aliyev, H. 2017. “Pro-regime Militias and Civil War Duration.” Terrorism and Political Violence. Online first.

Aliyev, H.2016. “Strong Militias, Weak States and Armed Violence: Towards a Theory of ‘State-parallel’ Paramilitaries.” Security Dialogue, 47(6), 498-516.

Aliyev, H., and Souleimanov, E.A. (2018). Ethnicity and Conflict. Accounting for the Effect of Co-ethnic and Non-ethnic Militias on Battlefield Lethality. Third World Quarterly. Forthcoming.

Barter, S.J. 2013. “State Proxy or Security Dilemma? Understanding anti-Rebel Militias in Civil War.” Asian Security, 9(2): 75-92.

Böhmelt, T., and Clayton, G. 2017. “Auxiliary Force Structure: Paramilitary Forces and ProGovernment Militias.” Comparative Political Studies. Forthcoming.

Buhaug, H., Gates, S., and Lujala, P. 2009. “Geography, Rebel Capability, and the Duration of Civil Conflict.” Journal of Conflict Resolution 53(4): 544-569.

Carey, S.C., Mitchell, N.J., and Lowe, W. 2013. "States, the Security Sector, and the Monopoly of Violence: A new Database on Pro-Government Militias.” Journal of Peace Research 50(2): 249-258.

Carey, S.C., Colaresi, M.P., and Mitchell, N.J. 2015. “Governments, Informal Links to Militias, and Accountability.” Journal of Conflict Resolution 59(5): 850-876.

Carey, S.C., Colaresi, M.P., and Mitchell, N.J. 2016. "Risk Mitigation, Regime Security, and Militias: Beyond Coup-proofing.” International Studies Quarterly 60(1): 59-72. 
Carey, S.C., and Mitchell, N.J. 2017. "Pro-Government Militias.” Annual Review of Political Science 20: 127-147.

Carey, S.C., Mitchell, N.J. and Scharpf, A. 2018. “The Composition of the Security Sector and the Duration of Counterinsurgency Campaigns.” Unpublished manuscript.

Carter Center. 2013. Syrian Countrywide Conflict Report No.1. Syrian Conflict Mapping Program, $20^{\text {th }}$ of August.(https://www.cartercenter.org/)

Cederman, L-E., Gleditsch, K.S., and Buhaug, H. 2013. Inequality, Grievances and Civil War. Cambridge: Cambridge University Press.

Cederman, L-E., Hug, S., Schädel, A., and Wucherpfennig, J. 2015. Territorial Autonomy in the Shadow of Conflict: Too Little, Too Late? American Political Science Review 109(2): 354-70.

Clayton, G., and Thomson, A. 2016. “Civilianizing Civil Conflict: Civilian Defense Militias and the Logic of Violence in Intrastate Conflict.” International Studies Quarterly 60(3): 499-510.

Collier, P., Hoeffler, A., and Söderbom, M. 2004. “On the Duration of Civil War.” Journal of Peace Research 41(3): 253-273.

Cunningham, D.E. 2006. "Veto Players and Civil War Duration.” American Journal of Political Science 50(4): 875-892.

Cunningham, D.E., Gleditsch, K.S., and Salehyan, I. 2009. “It Takes Two: A Dyadic Analysis of Civil War Duration and Outcome.” Journal of Conflict Resolution 53(4): 570-597.

Denny, E.K., and Walter, B.F. 2014. "Ethnicity and Civil War.” Journal of Peace Research 51(2): 199-212.

De Rouen, K. Jnr., Bercovitch, J and Pospieszna, P. 2011. “Introducing the new Civil Wars Mediation (CWM) Dataset.” Journal of Peace Research 48(5): 663-672. 
Eck, K. 2009. “From Armed Conflict to War: Ethnic Mobilization and Conflict Intensification.” International Studies Quarterly 53(2): 369-388.

Fjelde, H., and Hultman, L. 2014. "Weakening the Enemy: A Disaggregated Study of Violence against Civilians in Africa.” Journal of Conflict Resolution 58(7): 12301257.

Gates, S., and Strand, H. 2004. “Modeling the Duration of Civil Wars: Measurement and Estimation Issues.” Unpublished Manuscript.

Gleditsch, N.P., Wallensteen, P., Eriksson, M., Sollenberg, M., and Strand, H. 2002. “Armed Conflict 1946-2001: A New Dataset.” Journal of Peace Research 39(5): 616-37.

Gleditsch, K.G. 2002. “Expanded Trade and GDP Data.” Journal of Conflict Resolution 46(5): 712-725.

Gurcan, M., 2015. “Arming civilians as a counterterror strategy: The case of the village guard system in Turkey.” Dynamics of Asymmetric Conflict, 8(1), pp.1-22.

Harkness, K.A., 2016. “The ethnic army and the state: Explaining coup traps and the difficulties of democratization in Africa.” Journal of Conflict Resolution, 60(4), pp.587-616.

Hendrix, C., and Young, J. 2014. “State Capacity and Terrorism: A Two-Dimensional Approach.” Security Studies 23(2): 329-363.

Hegre, H, Hultman, L and Nygård, H.M. 2016. “Evaluating the conflict-reducing effect of UN peacekeeping operations.” Unpublished Manuscript.

Ho, D., Kosuke, I., King, G., and Stuart, E. 2007. “Matching as Nonparametric Preprocessing for Reducing Model Dependence in Parametric Causal Inference.” Political Analysis 15: $199-236$

Idris, A. (2005). Conflict and politics of identity in Sudan. London: Springer.

Jentzsch C. (2014). “Militias and the Dynamics of Civil War.” PhD Dissertation Yale 
University.

Jentzsch, C., Kalyvas, S.N., Schubiger, L.I. 2015. “Militias in Civil Wars.” Journal of Conflict Resolution 59(5): 755-769.

Johnson, D.H. 2003. The Root Causes of Sudan's Civil Wars. Bloomington, IN: Indiana University Press.

Kalyvas, S.N. 2006. The Logic of Violence in Civil War. Cambridge: Cambridge University Press.

Kalyvas, S.N. 2008. "Ethnic Defection in Civil War. Comparative Political Studies 41(8): 1043-1068.

Kaufmann, C. 1996. "Possible and Impossible Solutions to Ethnic Civil Wars.” International Security 20(4): 136-175.

Kirschke, L. 2000. “Informal Repression, Zero-Sum Politics and Late Third Wave Transitions.” The Journal of Modern African Studies 38(3): 383-405.

Kirschner, S.A. 2010. “Knowing Your Enemy: Information and Commitment Problems in Civil Wars.” Journal of Conflict Resolution 54(5): 745-770.

Koren, O., 2017. Means to an end: Pro-government militias as a predictive indicator of strategic mass killing. Conflict management and peace science, 34(5), pp.461-484.

Kreutz, J. 2010. “How and When Armed Conflicts End: Introducing the UCDP Conflict Termination Dataset.” Journal of Peace Research 47(2): 243-250.

Lyall, J. 2010. “Are Co-ethnics More Effective Counterinsurgents? Evidence from the Second Chechen War.” American Political Science Review 104(1): 1-20.

Magid, Y., and J. Schon. 2018. “Introducing the African Relational Pro-Government Militia Dataset (RPGMD).” International Interactions 44(4): 801-832.

Marshall, G.M., and Jaggers, K. 2006. Polity IV Project: Political Regime Characteristics and Transitions, 1800-2006. (http://www.systemicpeace.org/polity/polity4.htm). 
Martin, R. 2002. “Sudan's Perfect War.” Foreign Affairs: 111-127.

McLaughlin, T. 2010. “Loyalty Strategies and Military Defection in Rebellion.” Comparative Politics 42(3): 333-350.

Mitchell, N.J., Carey, S.C., \& Butler, C.K. 2014. “The Impact of Pro-Government Militias on Human Rights Violations.” International Interactions 40(5): 812-836.

Montalvo, J.G., and Reynal-Querol, M. 2010. “Ethnic Polarization and the Duration of Civil Wars.” Economics of Governance 11(2): 123-143.

Pilster, U., and Böhmelt, T. 2011. “Coup-Proofing and Military Effectiveness in Interstate Wars, 1967-99.” Conflict Management and Peace Science 28(4): 331-350.

Plümper, T., Troeger, V. E., and Manow, P. 2005. “Panel Data Analysis in Comparative Politics: Linking Method to Theory.” European Journal of Political Research 44(2): 327-354.

Posner, D.N. 2005. Institutions and Ethnic Politics and Africa. Cambridge: Cambridge University Press.

Raleigh, C. 2016. "Pragmatic and Promiscuous: Explaining the Rise of Competitive Political Militias across Africa.” Journal of Conflict Resolution 60(2): 283-310.

Raleigh, C. and Kishi, R., 2018. “Hired Guns: Using Pro-Government Militias for Political Competition.” Terrorism and Political Violence. Online first.

Roessler, P. 2011. “The Enemy Within: Personal Rule, Coups, and Civil War in Africa.” World Politics 63(2): 300-346.

Roessler, P. 2016. Ethnic Politics and State Power in Africa: The Logic of the Coup-Civil War Trap. Cambridge: Cambridge University Press.

Schneckener, U. 2006. “Fragile Statehood, Armed Non-State Actors and Security Governance” in: Bryden, A./ Caparini, M. (eds.) Private Actors and Security Governance. Berlin: Lit-Verlag, pp. 23-40 
Seymour, L.J.M. 2014. "Why Factions Switch Sides in Civil Wars: Rivalry, Patronage, and Realignment in Sudan.” International Security 39(2): 92-131.

Staniland, P. 2012. "Between a Rock and a Hard Place: Insurgent Fratricide, Ethnic Defection, and the Rise of Pro-State Paramilitaries.” Journal of Conflict Resolution 56(1): 16-40.

Stanton, J.A. 2015. "Regulating Militias: Governments, Militias, and Civilian Targeting in Civil War.” Journal of Conflict Resolution 59(5): 899-923.

Steinert, C.V., Steinert, J.I. and Carey, S.C., 2018. Spoilers of peace: Pro-government militias as risk factors for conflict recurrence. Journal of Peace Research.

Souleimanov, E.A., Aliyev, H. and Ratelle, J.F., 2018. Defected and loyal? A case study of counter-defection mechanisms inside Chechen paramilitaries. Terrorism and Political Violence, 30(4), pp.616-636.

Warren, T.C., and Troy, K.K. 2015. “Explaining Violent Intra-Ethnic Conflict: Group Fragmentation in the Shadow of State Power.” Journal of Conflict Resolution 59(3): 484-509.

Weinstein, J.M. 2007. Inside Rebellion: The Politics of Insurgent Violence. Cambridge: Cambridge University Press.

Wimmer, A. 2013. Ethnic Boundary Making: Institutions, Power, Networks. Oxford: Oxford University Press.

Wimmer, A., Cederman, L-E., and Min, B. 2009. "Ethnic Politics and Armed Conflict: A Configurational Analysis of a New Global Data Set.” American Sociological Review 74(2): 316-337.

Wucherpfennig, J., Metternich, N.W., Cederman, L.-E., and Gleditsch, K.S. 2012. “Ethnicity, the State, and the Duration of Civil War.” World Politics 64(1): 79-115. 